\title{
Effect of Pre-/ Postnatal Hypoxia on Pyruvate Kinase in Rat Brain
}

\author{
Afag M. Rashidova (id 1,* \\ ${ }^{1}$ Academician Abdulla Garayev Institute of Physiology, Azerbaijan National Academy of Sciences, Baku, \\ Azerbaijan
}

\begin{abstract}
The effect of hypoxic hypoxia on the pyruvate kinase (PK) activity in the brain structures of white rats during ontogenesis in a comparative aspect has been studied. A clear dependence could be established in the increase of PK activity from an oxygen deficient state, the age of animals, the studied structure of the brain and the prolonged effect of hypoxia. Prenatal exposure to hypoxia has shown that the PK activity is not restored to the control value level in postnatal development. After postnatal exposure to hypoxia with increasing age in animals, the PK activity gets more resistant to the effect of stress-factors. The data analysis indicates that the increasing exhaustion of energy resources necessary for normal cell functioning makes an important contribution to the development of hypoxic state and the insufficiency of mitochondrial oxidative phosphorylation, the main energy forming system which underlies these disturbances. Energy-shortage, in its turn causes a variety of secondary negative metabolic alterations and gives rise to free radical oxidation in the cells. An explanation of the obtained results suggested can be considered as an evidence of the realization of the biological effect of hypoxia through the oxidative mechanism.
\end{abstract}

\section{ARTICLE HISTORY}

Received: 17 April 2018

Revised: 23 July 2018

Accepted: 27 July 2018

\section{KEYWORDS}

Albino rats, Age, Hypoxia, Brain, Ontogenesis, Pyruvate kinase (PK).

\section{INTRODUCTION}

The literature review shows that prenatal and postnatal hypoxia affects the cardiovascular system, the vegetative balance and the central nervous system (CNS). In addition, from all the stressful effects that the fetus can undergo during the period of intrauterine development, hypoxia leads to embryo toxic effects and various pathologies of development. This is due to the fact that during the period of intrauterine development, most of the damaging factors realize their effect in the mother-placenta-fetus system. Prenatal hypoxia plays a decisive role in delaying the maturation of the nervous system and the higher brain functions in children. The effects of prenatal hypoxia on the body depend on the severity of the effect, of individual tolerance and the period of intrauterine development. In this aspect, the period of intensive organogenesis (13-17 days of development) is one of the critical periods of embryogenesis [1]. In the postnatal period, hypoxia leads to the accumulation of damaged molecules in cells which contribute to the development of diseases and the premature aging of the organism [2,3].

Hypoxia accompanied by oxidative stress causes the pathology of the body which is displayed in the destruction of mitochondria, the activation of free radical processes and

CONTACT: Afag M Rashidova $\bigotimes$ afag.rashidova@gmail.com $\equiv$ Academician Abdulla Garayev Institute of Physiology, Azerbaijan National Academy of Sciences, Baku, Azerbaijan. 
hypoxia of cells at all levels. In the course of normal metabolic reactions, active forms of oxygen are formed in the cells and their amount greatly increases during hypoxia [2]. Brain is hypersensitive to hypoxia [4,5]. A lot of enzymes are affected by hypoxia [6]. It was proven that the first response of the body to hypoxia is the synthesis of the factor HIF-1, which regulates the transcription of genes encoding some enzymes of glycolysis [7].At present, pyruvate kinase (PK; EC 2.7.1.40) is considered as a sensible and critical target for free radicals under hypoxic stress and a sharp increase was shown in PK activity [8-10].

The main objective aim of this paper is to study -in a comparative aspect- the activity of energy metabolism enzyme in the brain structures of rats exposed to pre- and postnatal hypoxia. The investigation of aged dynamics of PK activity in brain structures during hypoxia will bring some clarity into the mechanisms of redox-alterations in the brain. The study of the hypoxic effect on the energy metabolism of the brain makes it possible to evaluate the functional reserves of the organism in activities associated with changes in the conditions of external respiration or the gaseous environment $[11,12]$.

\section{MATERIAL AND METHODS}

The experiments were conducted in 2 series on white nonlinear rats in mitochondrial (MF) and cytosolic fractions (CF) of orbital cortex (OC), limbic cortex (LC), sensorimotor cortex $(\mathrm{SMC})$, hypothalamus $(\mathrm{H})$ and cerebellum $(\mathrm{C})$. In the first series of the experiments, 20 albino female rats were exposed; the experimental group included the progeny of females subjected to hypoxia during the organogenesis of E13-E17 days.

PK activity was assayed on 17 (period of maturation), 30 (period of weaning, completion of earlier period of postnatal ontogenesis) and 90 (reproductive period) days of postnatal ontogenesis. The first two periods are considered critical in postnatal ontogenesis.

In the second series of experiments, adult male rats were subjected to hypoxia at 3-month or P90 (mass 90-110 gr), 6-month or P180 (mass 130-150 gr), 12-month or P360 (mass 190220 gr) of age. The pregnant and adult rats were exposed to hypoxia (for 20 minutes every day during 5 days in a special hyperbaric chamber with a volume of $0.012 \mathrm{~m}^{3}$ into which gas mixture of $5 \% \mathrm{O}_{2}$ and $95 \% \mathrm{~N}_{2}$ was supplied from gas cylinders, measured with a gas meter). In order to eliminate the effect of stress handling, an appropriate control group of animals of the same age was placed into the same hyperbaric chamber under normal oxygen content. The animals of both groups were sacrificed at the end of the experiments. The whole brains were quickly removed under hypothermia and then OC, SMC, LC, H and C were identified. MF and CF were removed with differential centrifugation [13]. PK activity was determined spectrophotometrically by the method of H.U. Bergmeyer (1975) [14]. Specific activity of PK was expressed in $\mu \mathrm{M} \mathrm{NADN} / \mathrm{mg}$ protein $/ 1 \mathrm{~min}$. The protein contents of the samples were determined according to the method of Bradford [15] with bovine serum albumin used as a standard.

The experiments were conducted in accordance with bioethical principles and guide line documents, recommended by the European Convention for the Protection of Vertebrate Animals used for Experimental and other Scientific Purposes (Strasbourg, ETS-№170; 02.12.2005). The reliability of the differences was determined by the " $t$ " Student test. The obtained data was processed by the method of variation statistics.

\section{RESULTS AND DISCUSSION}

In rats exposed to hypoxia prenatally during intensive organogenesis - one of the critical periods of intrauterine development, the time course of changes in PK activity - on P17, P30 and P90 days of postnatal ontogenesis was determined. 
While in the OC of P17-day rats hypo activity was observed in the PK activity, by 3month these indices exceeded the control value level by 4.5 times. In SMC, LC and $\mathrm{H}$, in spite of decreasing noticeably by P17 day $(45 \%, 54 \%$ and $70 \%$ correspondingly and relatively to the control value level), by P30 the PK activity increases by 2.5 times, but by P90 these indices have a tendency to decrease to the control value level.

As compared to the P17-day rats in P30-day ones PK activity in the brain structures increased by 1.2-2.5 times concerning to the controls. In 3-month-old rats, the PK activity changed unequally depending on the brain structures under study: in $\mathrm{C}$, OC and SMC it increased by 1.2-4.5 times, while in LC it decreased. In $\mathrm{H}$, it remained at the control value level. It should be noted that in $\mathrm{C}$ in all the periods of postnatal ontogenesis the PK activity was higher than the control value level $(105 \%, 179 \%$ and $116 \%)(p>0.05 ;<0.001 ;<0.05)$.
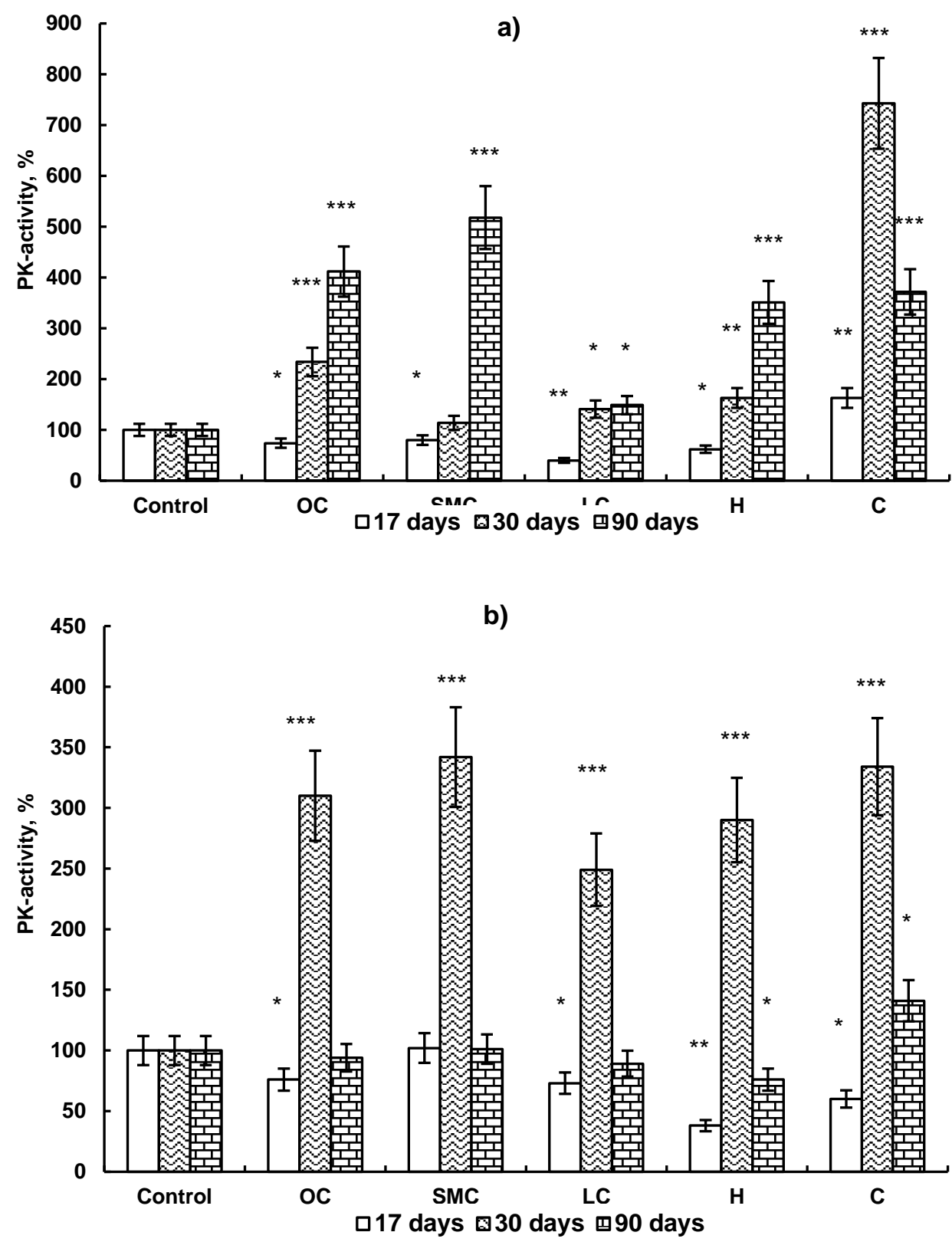

Figure 1.Time-relatedchanges in PK activity in: a) mitochondrial (MF) and b) cytosolic fractions (CF) of brain structures of rats exposed prenatally to hypoxia.

$*_{-}$p $<0.05 ; *_{-}$- $<<0.01 ; * * *_{-}$p $<0.001$, relatively to the control value level. 
In MF of brain structures of P17 days rats PK activity was lower than the control value level, with exception of $\mathrm{C}$ where it was higher than the control value level by $63 \%$ $(p<0.01)$.With age the enzyme activity showed an increase by 1.3-5.0 times $(p<0.01)$ in all the brain structures under study with the exception of $\mathrm{C}$, where by P30 the PK activity increased by7.5, while on P90 it decreased by 3.8 times (p<0.001) (Figure 1a).

In the SF of all the brain structures with the exception of SMC the next picture was observed: the PK activity decreased by 1.2-3.0 times by P17, on P30 it greatly increased by 2.53.5 times and on 90 day it decreased to the control value level $(\mathrm{p}<0.05 ;<0.001)$ (Figure $1 \mathrm{~b})$. The PK activity in $\mathrm{C}$ made upon exception as well as increasing by $41 \%$ as compared to the control value level.

As known, hypoxic damage of the developing brain can lead to death or psychic and neural generative diseases with age [16].Organogenesis period of intrauterine development can be considered as the most susceptive to a number of stressful factors. In that period of development proliferation occurs in the brain, migration processes and maturation of neuroblasts. The impairment of the proceeding of these processes can be considered as an initial cause of changes in physiological and behavioral reactions and cognitive functions in later ontogenesis, as well [17].

Therefore the consequences of hypoxia endured by foetus prenatally in the course of intensive organogenesis on E13-E17 affects postnatal ontogenesis, which are in agreement with the data of other authors [18]. In the tissues and subcellular fractions of brain structures PK activity decreased by 1.2-3.0 times on P17, while on P30 it increased by 1.5-7.0 times. On P90 days PK activity increased compared to the control value level and only in cytosol it decreased and reached the control value level. The elevation in PK activity by 30-day and 3-month-old ones can be explained by the preservation in the brain tissue functioning of optimized energy supply, as well. The balance of 2-sygnal ways is affected by prenatal hypoxia and the results in the intensification of extracellular $\mathrm{Ca}^{2+}$ entry mechanisms and this disbalance is most displayed in the earlier periods of ontogenesis [19]. With age in the respiratory chain of mitochondria, reliable decreasing in oxidase activity of cytochrome $\mathrm{C}$ was revealed, which generates active forms of oxygen that damage macromolecules (DNA, protein and lipids) and leads to diseases and aging. In its turn, aging can be caused by 2 ways: physiological or pathological [3]. Free radical theory takes leading place among other theories [20]. According to the last theory oxidative stress development in the conditions of deficiency of antioxidant system, first of all, promotes aging of the brain [21].

The results, obtained during postnatal hypoxia, are of indubitable interest which points to the different reaction of PK activity to hypoxic effect.

The lowest indices in PK activity of 3-month-old animals were observed in SMC (below $100 \%)$ and in $\mathrm{H}$, but in $\mathrm{LC}$ and $\mathrm{C}$ was hyperactivity of the enzyme (236\% and $281 \%$ correspondingly) $(\mathrm{p}<0.001 ;<0.001)$. At the MF level all the indices, in spite of being below the control value level, the lowest activity in the PK was in $\mathrm{M}(30 \%)$, but the highest activity was in OC $(94 \%)$. In SF of SMC and M the indices were reliably low ( $<<0.01)$; as compared to the other brain structures under study $(\mathrm{p}<0.01)$; in LC and $\mathrm{H}$ on the contrary, PK activity increased (122\% and $129 \%$, correspondingly; $\mathrm{p}<0.01 ;<0.01)$ (Figure 2 ). 

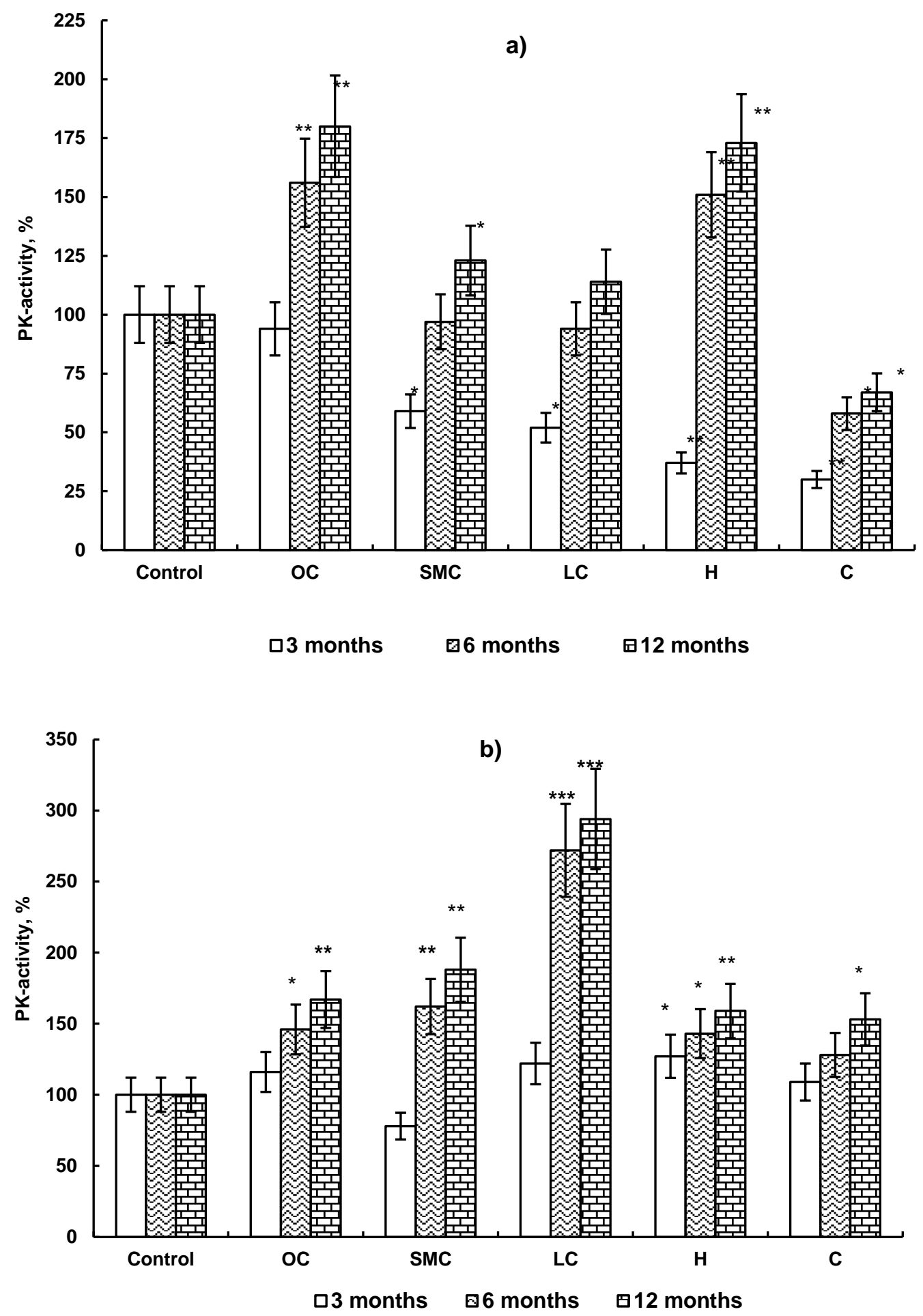

Figure 2.Time-related changes in PK activity in: a) mitochondrial (MF) and b) cytosolic fractions (CF) of brain structures of rats exposed to hypoxia in postnatal ontogenesis.

$*_{\text {- }}<<0.05 ; *_{\text {- }}$ $<0.01 ; * * *$ - $\mathrm{p}<0.001$, relatively to the control value level.

Unlike this age group in six-month-old rats, PK activity at all levels of $\mathrm{C}$ was low compared to the other brain structures. In $\mathrm{H}$, on the contrary, it increased in tissues and mitochondria (129 and 151\%), while in SF of LC the enzyme activity increased by 2.7 times $(\mathrm{p}<0.001)$. It should be noted that in six-month-old rats in MF of C PK activity was considerably lower than the control value level (58\%). 
In the group of 12-month-old rats, acomparative resistance of $\mathrm{PK}$ activity to oxygen deficiency was revealed. The time-course of changes in PK activity both in tissues and subcellular fractions of brain structures was identical with the enzyme activity of six-monthold rats. This indicates that with age animals become more steady to the influence of exogenous factors and adaptive-compensatory mechanisms are more developed in these animals (Figure $2 / \mathrm{a}$ and $2 / \mathrm{b}$ ). $\mathrm{C}$ in all the age groups turned out to be more sensitive to hypoxia.

There is no doubt that the mechanism to increase the activity of the enzyme in the brain during oxygen starvation is the enhancement of the glycolytic pathway of carbohydrate metabolism.

According to our results one can conclude that PK activity depends on the age, the brain structure under study and the subcellular fractions of this structure. In the OC, LC and H, the restoration of PK activity progresses more slowly than in SMC and C, which indicates that a definite level of metabolic processes corresponds to each functional state. The enzyme processes proceeding in the subcellular organoids of brain neurons allow enzyme adaptation in response to inadequate environmental situations both in brain and organism in general.

PK activity in spite of being at the same level in all the studied brain structures of the control group of animals, was fairly different in the experimental animals. One can assume that the influence of the products of breakdown on intracellular energy supply and the activation of biosynthetic processes in the brain, underlies the dynamics of changes in PK activity.

Under hypoxic conditions the disruption of the functional group of neurons that regulate the level of excitability of cortical neurons is one of the mechanisms of the development of pathological activity on the electro encephalo gramme (EEG) [22]. At the same time, it has been noticed, that based on a comparative analysis [23-25], it can be stated that the changes in the activity of the developing neurons under hypoxia lie in the same mechanisms that are typical for mature people. There are only some distinctive features [26,27]]. Also, the possible influence of this disturbance on the activity of enzymes of energy metabolism, including the PK of the brain, is not ruled out.

By comparing the data obtained in the two series of our experiments one can assume that the differences revealed in PK activity may be related to the individual features of the brain blood circulatory system in each age group. In most cases hypoxia leads to the development of deep disturbances in the metabolism of nervous cells which had a beneficial effect on the obtained results. However, in a number of cases adaptive-compensatory possibilities of the brain blood circulation was sufficient to cause considerable rebuilding in the metabolism and carry out temporal compensation of metabolic disturbances. The fact that PK activity was kept close to the control value levels in experimental animals can be a confirmation of this.

Energy metabolism in the brain differs from other tissues by its high reactivity and plays an important role in the adaptation of the functional state of the whole organism to stressful factors. The dynamics of changes in PK-activity in brain structures of rats exposed to hypoxia on E13-E17 days of intensive organogenesis, did not show restoration of PK activity up to the control indices on P17, P30 and P90 days ( $<<0.01 ;<0.001)$. The results show that hypoxia given to foetus during organogenesis leads to changes in the glycolysis process in the brain structures that bears an irreversible character.

The results of postnatal exposure to hypoxia on P90, P180 and P360 days showed that with increasing age, animals become more resistant to the effects of exogenous stress factors, indicating switching on more mature adaptive-compensatory mechanisms in these age groups $(\mathrm{p}<0.01)$. The highest resistance was observed in cortical structures. These data are considered as an evidence of therealization of thebiological effects of hypoxia through oxidative mechanism. 
The study of the age-related changes in the PK-activity in the brain structures in response to hypoxia will allow understanding the mechanisms of redox-shifts in the brain, subjected to hypoxia in prenatal and postnatal periods of ontogenesis.

Though the progeny themselves were not exposed to hypoxia, thetransmission of the observed changes in the PK activity by epigenetically or other way from themothercan beconfirmed. Hypoxia exerts negative effect on synaptic apparatus of neurons in various cortical and subcortical structures of progeny brain [28].

According to the results of the hypoxia on P90, P180 and P360 days of postnatal ontogenesis one can conclude that with age the animals seems to be more steady to exogenous stressful factors that points to thegreater development of adaptive- compensatory mechanisms in these animals. An elevation in PK activity under hypoxia can be related to the brain ability to prevent metabolic disturbances in the mechanisms of regulation of biosynthetic and bioenergetic processes in nervous cells under stressful factors. The impact of pre- and postnatal hypoxia produces typical changes in the system of energy metabolism and in connection with its close interaction with functional-metabolic status of the organism, it is anecessary correction of theconsequences of energy-shortage in thebrain.

According to the authors, a short acute hypoxic effect on the body makes it possible to studythe compensatory-adaptive mechanisms to overcomegrowing hypoxemia [12]. If the hypoxic factor is not eliminated and the accumulation of acid metabolic products continues, then from the $7-10^{\text {th }}$ minute of hypoxia, the tissue compensation mechanisms-thesecondary reactions of the body to oxygen deficiency are included in the body [29]. The reduction of oxygen in the blood inhibits cellular metabolism, reduces the formation of ATP and, consequently, the work of energy-dependent ion channels. The disruption of the operation of ion pumps and the transport of $\mathrm{Na}, \mathrm{K}$ and $\mathrm{Ca}$ ions, in turn, leads to a change in the duration of the action potential [30]. At this time the secondary tissue mechanisms for the compensation of the organism in response to oxygen deficiency occur after the $7^{\text {th }}$ minute of hypoxic exposure [29]]. Our results agree with these opinion.

Consequently the study shows the high sensibility of PK in brain structures to the influence of hypoxia in pre- and postnatal ontogenesis. The present work will be able to help with decisionsconcerningsome questions of energy supply in stressful conditions.

\section{CONCLUSION}

The data analysis indicates that increasing exhaustion of energy resources necessary for normal functioning of the cell makes an important contribution to the development of hypoxic state and the insufficiency of mitochondrial oxidative phosphorylation - the main energy forming system which underlies these disturbances. Energy-shortage, in its turn causes a variety of secondary negative metabolic alterations and gives rise to free radical oxidation in the cells. Owing to the high reactivity of free radicals, many components of the cell becomes the target of chemical lesions. The activation of lipid peroxidation processes leads to the modification or damaging the main functions of biological membranes. A distinctive range develops: oxygen deficiency disturbs energy metabolism and stimulates the free radical oxidation which by damaging the membranes of mitochondria makes deeper energy shortage in the cell.

\section{Acknowledgement}

The author gratefully acknowledges the generous financial support of Azerbaijan National Academy of Sciences, grant 0111AZ321 № 27.21:20.27.25.

\section{ORCID}

Afag M Rashidova (D) https://orcid.org/0000-0002-1452-3086 


\section{REFERENCES}

[1]. Shvyreva, E., Graf, A., Maslova, M., Maklakova, A., Sokolova, N. (2017). Acute hypoxic stress in the critical periods of embryogenesis: the influence on the offspring developmentin the early postnatal period. European Neuropsycho pharmacology, ed. Elsevier BV (Netherlands), 27(9), 105. https://istina.msu.ru/publications/article/74505542/

[2]. Menshchikova, E.B., Lankin, V.Z., Zenkov, N.K. (2006). In: Oxidative stress. Proxidants and antioxidants. M.: "Slovo", 556 p. https://www.twirpx.com/file/908751/

[3]. Anisimov, V.N. (2008). Molecular and Physiological Mechanisms of Aging., v1, 481 p., St. Petersburg. http://www.gerontology.ru/PDF_library/Book-Anisimov_t-1-2008.pdf

[4]. Zhuravin, I.A., Tumanova, N.L., Ozirskaya, E.V., Vasiliev, D.S., Dubrovskaya, N.M. (2007). Formation of structural and ultrastructural organization of striatum in postnatal ontogenesis of rats with changing conditions of their embryonic development. J.Evol. Biochim. Fiziol., 43(2), 229-239. DOI 10.1134/50022093007020123

[5]. Mishra, O.P., Delivoria-Papadopoulos, M. (1999). Cellular mechanisms of hypoxic injury in the developing brain. Brain Res Bull., 48(3), 233-238. PMID 10229330; https://www.ncbi.nlm.nih.gov/pubmed/10229330

[6]. Pellerin, L., Magistretti, P.J. (2003). How to balance the brain energy budget while spending glucose differently. J. Physiology, 546(2), 325. DOI: 10.1113/jphysiol.2002.035105. PMCID: PMC2342533. PMID: 12527720.

[7]. Semenza, G.L. (2012). Hypoxia-inducible factors in physiology and medicine. Cell. Feb 3; 148(3), 399-408. DOI: 10.1016/j.cell.2012.01.021.

[8]. Рашидова, А.М., Гашимова, У.Ф. (2017). Зависимость активности ферментов ЛДГ и ПК в тканях структур головного мозга белых крыс от уровня гипоксии, перенесенной на стадии органогенеза ж.Известия НАНА, 72(1), 121-125. http://www.jbio.az/uploads/journal/e70929ecd0b2172f1485c15aaed81c57.pdf

[9]. Belova, N.G., Zhelev, V.A., Agarkova, L.A., Kolesnikova I.A., Gabitova N.A. (2008). Features of energy metabolism of cells in the mother-fetus-newborn system in pregnancy complicated by gestosis. Сибирский медицинский журнал, 4-1(23), 7-10.

[10]. Лукьянова, Л. Д. (2001). Митохондриальные дисфункции при гипоксии -типовой патологический процесс./Митохондрии в патологии. Материалы всероссийского рабочего совещания.-Пущино, 2001.-С. 66-67; https://readera.ru/metabolicheskajamoduljacija-protivoopuholevogo-jeffekta-citostatikov-v-14045499

[11]. Prabhakar, N.R. (2013). Sensing hypoxia: physiology, genetics and epigenetics. J. Physiol., 591(9), 2245-2257. DOI: 10.1113/jphysiol.2012.247759

[12]. Zamenina, E.V., Panteleeva, N.I., Roshchevskaya, I.M. (2017). The heart electric field of man during ventricularrepolarization under hypoxic influence. Russian J. of Physiology, 103(11). 1330-1339. https://elibrary.ru/item.asp?id=30511338

[13]. Chinopoulos, C., Zhang, S.F., Thomas, B., Ten, V., Starkov, A.A. (2011). Isolation and functional assessment of mitochondria from small amounts of mouse brain tissues. Methods Mol. Biol., 793, 311-324. DOI: 10.1007/978-1-61779-328-8_20

[14]. Bergmeyer, H.U. (1975). Biochemica information. In: Methods of Enzymatic Analysis, II. 82-83.

https://books.google.az/books?id=jgIlBQAAQBAJ\&pg=PA157\&dq=Bergmeyer+H.U.+( 1975).+Biochemica+information.\&hl=ru\&sa=X\&ved=0ahUKEwiNnt3b06PcAhUDlSw KHWbJDQgQ6AEILDAB\#v=onepage\&q=Bergmeyer\%20H.U.\%20(1975).\%20Bioche $\underline{\text { mica\%20information. } \& \mathrm{f}=\text { false }}$ 
[15]. Kruger, N.J. (2009). The Bradford method for protein quantitation. The protein Protocols Handbook, 3-rd ed. Ed. by J.M.Walker, Humana press Inc., Totowa N.J.,: 17-24. https://www.springer.com/gb/book/9781588298805

[16]. Fatemi, A., Wilson, M.A., Johnston, M.V. (2009). Hypoxic Ischemic Encephalopathy in the Term Infant. Clin Perinatol., 36(4), 835. DOI: 10.1016/j.clp.2009.07.011

[17]. Граф, А.В., Гончаренко, Е.Н., Соколова, Н.А., Ашмарин, И.П. (2008). Антенатальная гипоксия: участие в развитии патологий ЦНС в онтогенезе. Нейрохимия, 25(1-2), 1116. http://naukarus.com/antenatalnaya-gipoksiya-uchastie-v-razvitii-patologiy-tsns-vontogeneze

[18]. Zhuravin, I.A., Tumanova, N.L., Vasilyev, D.S. (2009). Change in adaptive mechanisms of the brain in the ontogenesis of rats underwent prenatal hypoxia. Reports of the Academy of Sciences, 425(1), 123-125. http://naukarus.com/izmenenie-adaptivnyh-mehanizmovmozga-v-ontogeneze-krys-perenesshih-prenatalnuyu-gipoksiyu

[19]. Stroyev, S.A., Tyulkova, E.I., Vataeva, L.A., Samoilov, M.O., Pelto-Huikko, M.T. (2011). Effect of prenatal hypoxia on the expression of thioredoxin-1 in the rat hippocampus at different times. Нейрохимия, 28(3), 226-231. https://elibrary.ru/item.asp?id=16655351

[20]. Speakman, J. R., Selman, C. (2011). The free-radical damage theory: Accumulating evidence against a simple link of oxidative stress to ageing and lifespan. BioEssays: news and reviews in molecular, cellular and developmental biology, 33(4), 255-259. DOI:10.1002/bies.201000132.

[21].Harman, D. (2006). Free Radical Theory of Aging: An Update Increasing the Functional Life Span. Annals of the NY Academy of Sciences, 10 May: 10-21. DOI:10.1196/annals.1354.003

[22]. Huseynov, A. H. (2017) Mechanism of impact of hypoxia on general activity of brain cortex. Russian Journal of Physiology, 103(11), 1209-1224. https://elibrary.ru/item.asp?id=30511329

[23]. Ballanyi, K.J. (2004). Protective role of neuronal KATP channels in brain hypoxia. J. Exp. Biol., 207, 3201-3212. DOI: 10.1242/jeb.01106

[24]. Nieber, K. (1999). Hypoxia and neuronal function under in vitro conditions. Pharmacol. Ther., 82(1), 71-86. PMID: 10341358; https://www.ncbi.nlm.nih.gov/pubmed/10341358

[25]. van Os, S., Ruitenbeek, W., Hopman, J., van de Bor, M. (2006). Excitatory amino acid release and electrocortical brain activity after hypoxemia in near-term lambs. Brain Dev., 28, 380-388. DOI: 10.1016/j.braindev.2005.12.002

[26]. Luhmann, H.J., Kral, T., Heinemann, U. (1993). Influence of hypoxia on excitation and GABA-ergic inhibition in mature and developing rat neocortex. Exp. Brain Res., 97, 209224. https://link.springer.com/article/10.1007/BF00228690

[27]. Nolan P.C., Waldrop T.G.(1996). In vitro responses of VLM neurons to hypoxia after 320 normobaric hypoxic acclimatization. Respiration Physiology, 105(1-2), 23-33; DOI.ORG/10.1016/0034-5687(96)00033-3; https://www.sciencedirect.com/science/article/pii/0034568796000333

[28]. Hanse E., Taira T., Lauri S., Groc L. (2009). Glutamate synapse in developing brain an integrative perspective beyond the silent state. Trends Neurosci., 32(10), 532-537. DOI: 10.1016/j.tins.2009.07.003. Epub 2009 Sep 4.

[29]. ГоранчукВ.В., СаповаН.И., ИвановА.О. (2003). Гипокситерапия. Изд-во ЭЛБИСПб.; 536 c. https://www.mmbook.ru/catalog/raznoe/101625-detail

[30]. Лукьянова, Л.Д., Ушаков, И.Б. (2004). Проблемы гипоксии: молекулярные, физиологические и медицинские аспекты. М., Истоки., 584 с., https://elibrary.ru/item.asp?id=19523467 